International scientific and technical conference

DOI: $10.34185 / 1991-7848 . i t m m .2020 .01 .017$

\title{
КІНЦЕВО-ЕЛЕМЕНТНОЇ РОЗРАХУНОК КУЛЬОВОГО ШПИНДЕЛЯ
}

Кононов Д. О., к.т.н., доцент, Пінто Ж. Б., магістр, Національна металургійна академія Украйни

Ключові слова: КУЛЬКОВИЙ ШПИНДЕЛЬ, НАПРУЖЕНОДЕФОРМОВАНИЙ СТАН, МЕТОД КІНЦЕВИХ ЕЛЕМЕНТІВ.

Вступ. Розробка і впровадження комп'ютерних технологій проектування інженерних систем в інтегрованому середовищі CAD/CAE стає вкрай актуальною в зв'язку з необхідністю підприємств іноді тісно співпрацювати та жорстко конкурувати з зарубіжними фірмами, інтенсивно використовують програмне забезпечення у виробничій діяльності.

у сучасному прокатному виробництві приділяється особлива увага вдосконаленню шпинделів і муфт в лініях приводів основного і допоміжного обладнання прокатних станів. Удосконалення йде шляхом створення абсолютно нових конструкцій, що забезпечують надійну роботу в умовах зростаючих швидкостей прокатки $\mathrm{i}$ тривалий термін служби змінного обладнання.

У світовій практиці відомо багато конструкцій шпиндельних з'єднань [0]. Основні з них міцно увійшли в практику сортових, листових і трубних станів: трефові, зубчасті, універсальні з шарнірами на бронзових вкладишах і на підшипниках кочення. Останнім часом стали використовувати нові конструкції шпинделів і муфт з шарнірами на тілах кочення.

На підставі численних досліджень умов роботи шпиндельних з'єднань та муфт прокатних станів [0-0] розроблені нові конструкції різних типів, які мають значно вищу довговічність, ніж відомі шпинделі і муфти, що застосовуються в приводах прокатних станів. Нові шпинделі і муфти прості у виготовленні мають високу навантажувальну здатність, знижують биття шпинделів і вібрації робочих валків, володіють підвищеною надійністю і довговічністю, підвищують стабільність процесу і точність прокатки.

Методика розрахунку шпинделів на тілах кочення мало досліджена. Варто відзначити роботи О.М. Комарова [0, 6], В якій вперше зроблена спроба 
аналітичного розрахунку напружено-деформованого стану, а також [7] В якій для розрахунку використовується можливості сучасних CAD/CAE систем.

Основна частина досліджень. 3 досвіду експлуатації відомо, що в умовах рівномірного розподілу сил між кулями шпинделя його обойма має багаторазовий запас міцності при заданому навантаженні. Поломка шпинделя відбувається за причиною нерівномірної роботи кульок в зачепленні, а також можливого їх підклинювання. Тому для оцінки несучої здатності шпинделя можна розглянути тільки роботу одного шарніра, що складається з обойми, головки і кульок.

Загальний вигляд тримірної параметричної моделі шпинделя показана на рис. 1.

Через великі моменти, що передаються шарніром, він виконаний без сепаратора, тому при передачі крутного моменту з перекосом обойми щодо

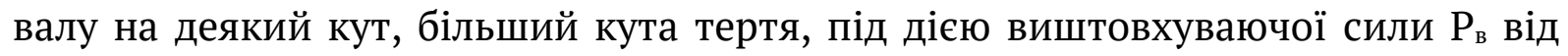
реакцій $\mathrm{R}_{\mathrm{O}} 3$ боку пазів обойми $\mathrm{i} \mathrm{R}_{\Gamma}$ з боку головки валу відбувається ковзання куль. Ковзання можливо до упору кулі в обмежувальну сферичну поверхню паза головки валу. В результаті відбувається порушення геометричної умови сталості контакту куль з пазами. Навантаження на кулі стає нерівномірним, оскільки частина куль може вийти із зачеплення.

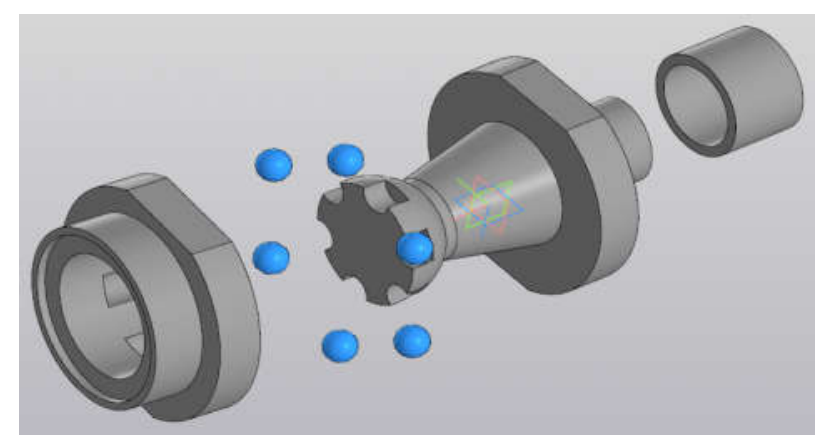

Рисунок 1 - Загальний вигляд просторової параметричної моделі шпинделя

Для виконання розрахунків в умовах нерівномірного навантаження куль була розроблена схема навантаження обойми, за допомогою якої проводилися дослідження їi напружено-деформованого стану, визначалися напруги в матеріалі обойми і критичні (допустимі) кути перекосу $\alpha$ при моменті, що дорівнює 2500 - 12000 Н · м.

Розробка кінцево-елементної моделі. 
International scientific and technical conference

Information Technologies in Metallurgy and Machine building - ITMM 2020

1. Моделювання контактної взаємодії

У шарнірі даної конструкції у кульки є такі контактні групи:

з головкою: три пари «сфера - циліндр», контакт по лінії; одна пара «сфера - лінія», точковий контакт;

3 обоймою: дві пари «сфера - циліндр», контакт по лінії; одна пара «сфера - лінія», точковий контакт.

Контакт моделювався, як нелінійний контакт, який дозволяє враховувати реальні неідеалізовані умови контакту (ковзання, втрата контакту) Розрахунковий коефіцієнт тертя поверхонь контакту прийнятий рівним 0,1.

2. Розрахунковий момент прикладався до голівки та обоймі.

3. Для підвищення точності розрахунку задавалася дрібною сіткою в області контакту кульки з пазами (розміри варіювалася 1 - 5 мм).

Результати моделювання. Було проведено кілька розрахункових модуляцій для декількох варіантів навантаження і стану шпинделя.

Розраховано напружено-деформований стан при співвісний розташуванні голівки i обойми (кут перекосу відсутня) досліджувався здатність навантаження вузла шарніра при перекосі шарніра.

Типовий вид отриманої напружено-деформованого стану шпинделя, при одній з розрахункової реалізації показано на рис. 2-3. (вид головки з кулькою, обойма не показана). Навантаження рівномірно розподілена між шістьма кульками.

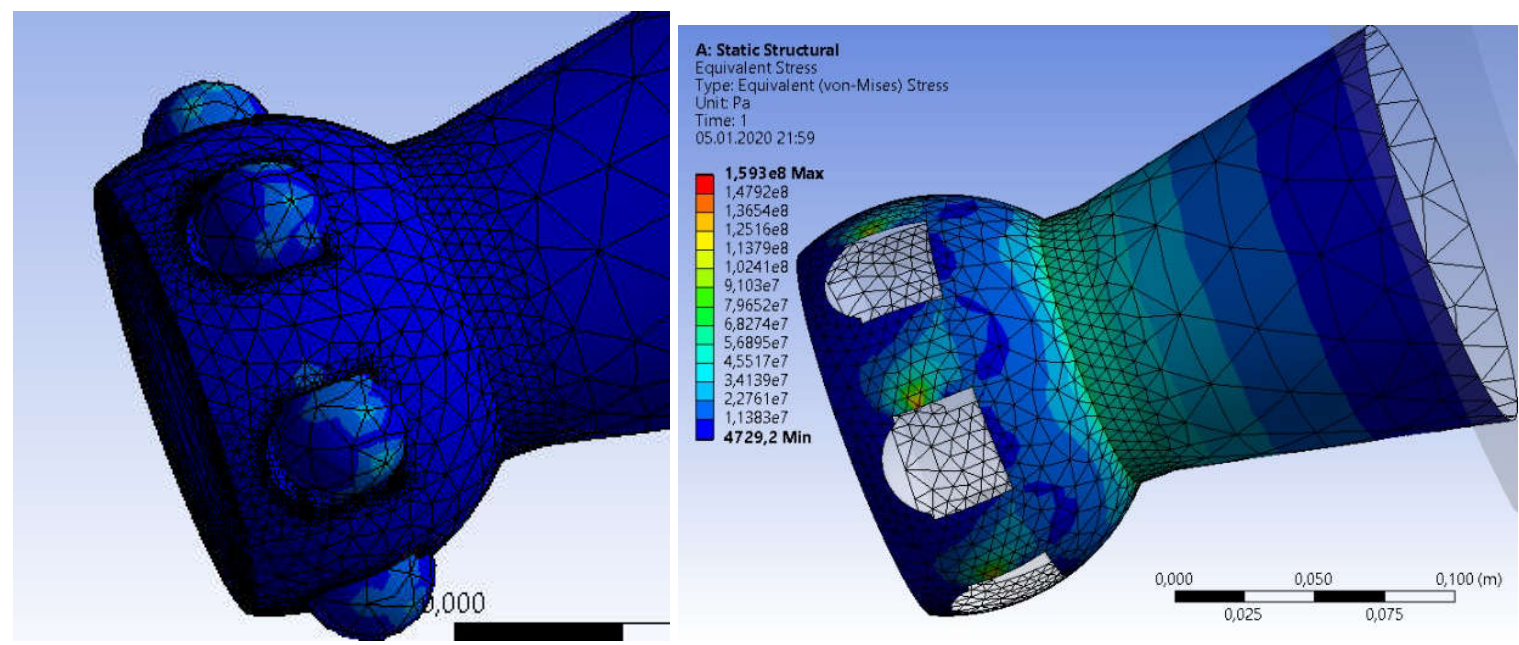

Рисунок 2 - Напружено-деформований стан головки

(кульку і лунки умовно не показані) 
Ministry of Education and Science of Ukraine

The National Metallurgical Academy of Ukraine, Dnipro, 17 - 19 March, 2020

При існуючій конструкції пазів в голівці і обоймі, при перекосі, виникає сила, яка виштовхує кулю з шарніра. В цьому випадку, навантаження кульки зростає, так як з'являється зона точкового контакту і цій точці з'являються великі напруги.
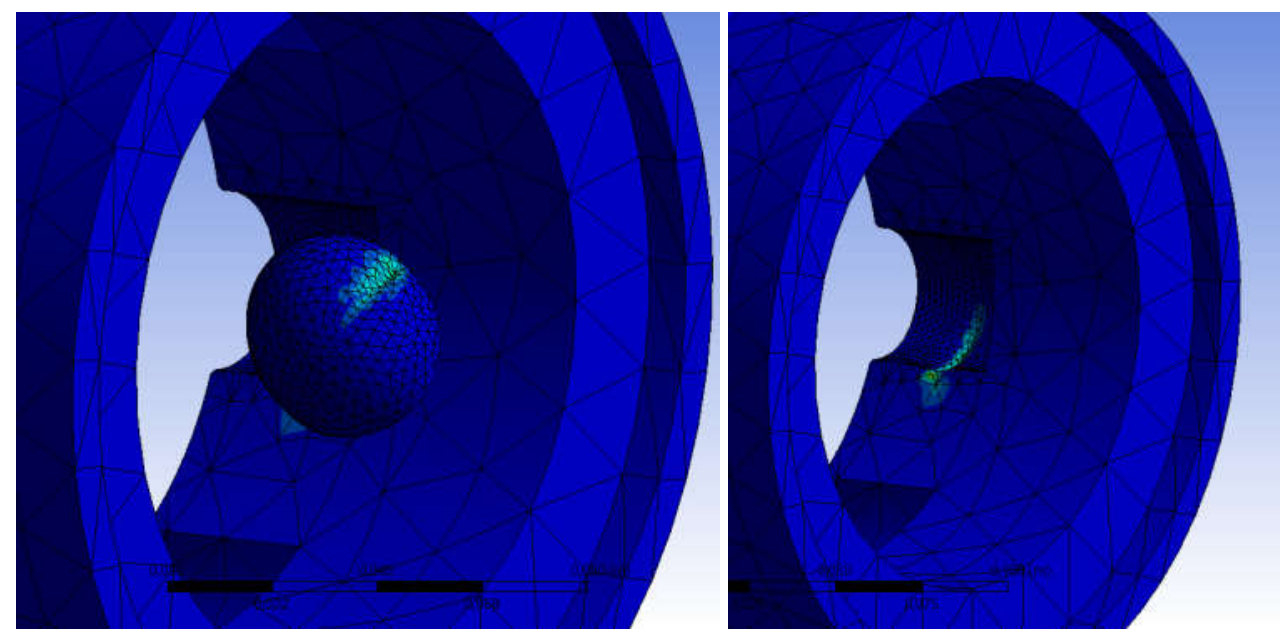

Рисунок 3 - Напружено-деформований стан обійми

(кульку і лунки умовно не показані

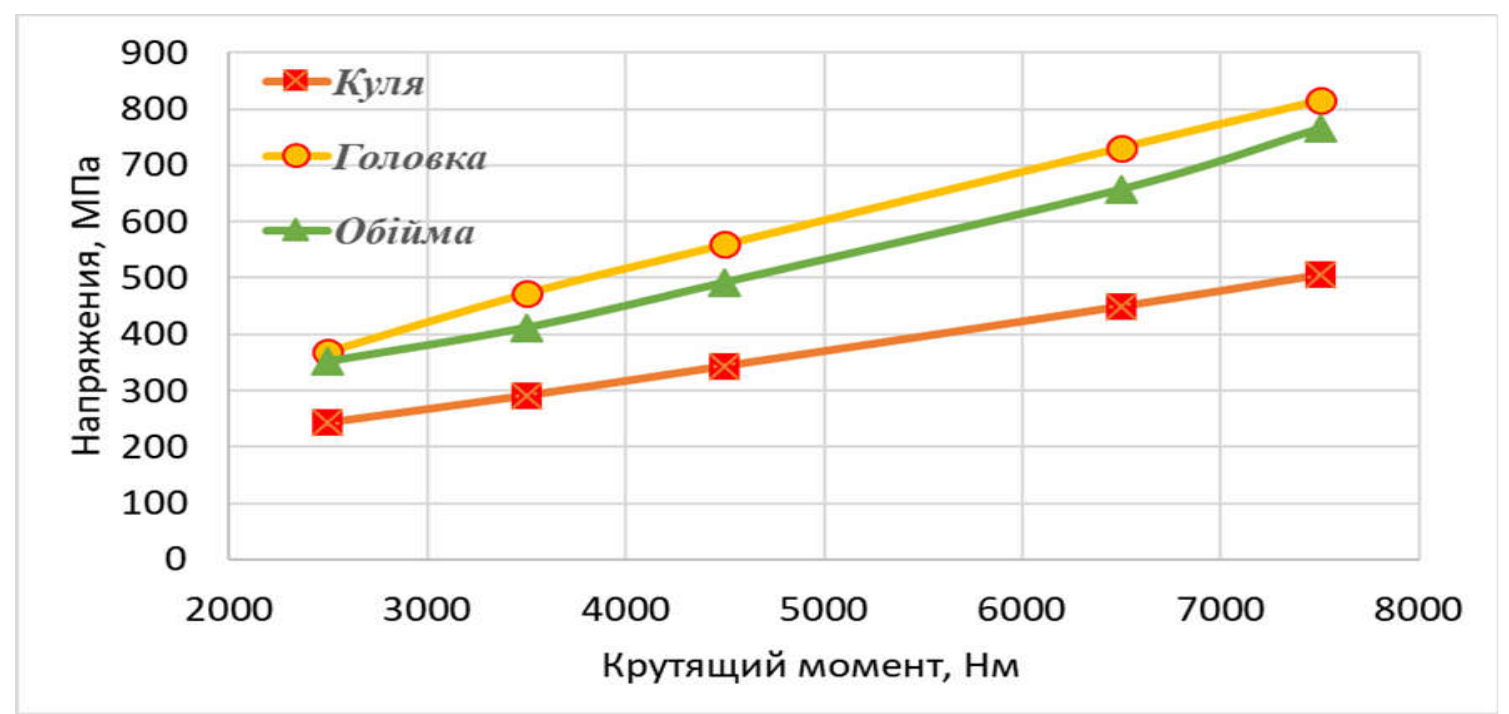

Рисунок 4 - Навантажувальна характеристика кульового шпинделя при двох кульках і кута перекосу $2^{\circ}$

\section{Висновки}

Розроблено параметричну тривимірну модель кульового шпинделя, яка дозволила моделювати положення головки, куль і обойми в залежності від кутів перекосу осей головки і обойми, кутів повороту головки щодо своєї осі.

Побудовано залежність максимальних еквівалентних напружень в кульовому шпинделі (в тілі шпинделя) і по поверхнях в елементах кульового шпинделя. При максимальному моменті, що крутить 12000 Нм, еквівалентні 
International scientific and technical conference

Information Technologies in Metallurgy and Machine building - ITMM 2020

напруження досягають значень: головка 484,3 МПа, обойма 423,7 МПа, контактні - 646 МПа.

Промоделювати робота кульового шпинделя при розподілі навантаження тільки між двома кульками. Побудований графік електричного навантаження на кульового шпинделя при двох кульках і куту перекосу $2^{\circ}$.

\section{Література}

1. Машины и агрегаты металлургических заводов. Т. 3: Машины и агрегаты для производства и отделки проката А. И. Целиков, Е И. Полухин, В. М. Гребеник и др. - М.: Металлургия, 1989. - 576с., илл.

2. Комаров А. Н Разработка основ взаимодействия технологии и оборудования главных линий прокатных станов с целью понижения стабильности процесса и точности прокатки. На соискание ученой степени доктора технических наук. Днепропетровск, 1981.- 460с., илл.

3. Патент Украины 245У МКИ В21В 35/14. Универсальный шарнир /А. Н. Комаров, 1994.

4. Патент Украины 12397А ММ В21B 35/14. Универсальный шарнир /А. Н. Комаров, Е. И. Фурманский, $1996 c$.

5. Патент Украины 14693А МКИ В21B 35/14. Шпиндельное соединение /А. Н. Комаров, Е. И. Фурманский, 1997.

6. Комаров А.Н. Шпиндели и муфты с шарнирами на телах качения для тяжелых машин (прокатных станов). Днепропетровск: ДНВП “Системные технологии”, 1998. 276 c.

7. Плахтин В. Д., Ивочкин М. Ю., Дмитрюк С. О. Исследование шарнира шарового шпинделя стана 250 // САПР и графика. 2011. № 4. С. 32-35.

\section{FINITE ELEMENT CALCULATION OF BALL SPINDLE}

\section{Kononov Dmitry, Pinto Jose Broni}

Anotation. A parametric three-dimensional model of the ball spindle was developed, which made it possible to simulate the positions of the head, balls and cage depending on the skew angles of the axes of the head and cage, the angles of rotation of the head relative to its axis.

Using the finite element method, the stress-strain state of the ball spindle is calculated at its various positions. 
The dependences of the maximum equivalent stresses in the ball spindle (in the spindle body) and on the surfaces in the elements of the ball spindle are obtained. With a maximum (according to the passport) torque of $12,000 \mathrm{Nm}$, the maximum stresses reach values: equivalent - a head of $484.3 \mathrm{MPa}$, a clip of $423.7 \mathrm{MPa}$; contact - $646 \mathrm{MPa}$.

The work of the ball spindle is simulated with load distribution only between two balls. A graph of the load capacity of the ball spindle with two balls and an angle of distortion of $2^{\circ}$.

With the existing design of the grooves in the head and holder, when skewed, a force arises that pushes the ball out of the hinge. In this case, the loading of the ball increases, since a zone of point contact appears and large stresses appear at this point.

Key words: BALL SPINDLE, STRESS-STRAIN STATE, FINITE ELEMENT METHOD.

\section{References}

1. Machines and assemblies of metallurgical plants. T. 3: Machines and assemblies for the production and decoration of rolled products A.I. Tselikov, E I. Polukhin, V.M. Grebenik, etc. - M .: Metallurgy, 1989. - 576 pp..

2. Komarov A. N Development of the fundamentals of the interaction of technology and equipment of the main lines of rolling mills in order to reduce the stability of the process and the accuracy of rolling. For the degree of Doctor of Technical Sciences. Dnepropetrovsk, 1981.- 460p.

3. Patent of Ukraine 245U MKI V21V 35/14. Universal Joint / A. N. Komarov, 1994.

4. Patent of Ukraine 12397A MM B21B 35/14. Universal Joint / A. N. Komarov, E.I. Furmansky, 1996.

5. Patent of Ukraine 14693A MKI B21B 35/14. Spindle connection / A. N. Komarov, E.I. Furmansky, 1997.

6. Komarov A.N. Spindles and couplings with hinges on rolling elements for heavy machines (rolling mills). Dnepropetrovsk: DNVP "System Technologies", 1998. - 276 p.

7. Plakhtin V. D., Ivochkin M. Yu., Dmitryuk S. O. Investigation of the ball joint of the spindle of the mill 250 // CAD and graphics. 2011. No. 4. P. 32-35. 